\title{
A NEW ROLE OF CAUSATION THEORY TOWARDS ACHIEVING ECONOMIC CONTRACTUAL EQUILIBRIUM: ANNULLING THE ARBITRARY CONTRACTUAL CONDITIONS
}

\author{
Osama Ismail Mohammad Amayreh* \\ Izura Masdina Mohamed Zakri** \\ Pardis Moslemzadeh Tehrani*** \\ Yousef Mohammad Shandi****
}

\begin{abstract}
The phrase "who says contractual, says justice" (qui dit contractuel dit juste) does not fully express the truth of present reality, where the phrase itself falls into doubt, since a contract does not always result in fair obligations. In this regard, the French judiciary realized that the absence of justice in a contract might arise as a result of the contractual freedom afforded to the contracting parties. Thus, the idea of Commutative Justice in the contract was developed, such as, the Chronopost's decision which is considered one of its most important applications. However, the equivalence of rights and obligations in the Palestinian Draft Civil Code only exists in a virtual form, without any content that actually contributes to the achievement of the equivalence between rights and obligations in contracts. This article seeks to prove that the provisions of the causation theory in the Palestinian Draft Civil Code can be used as an effective means for achieving contractual justice between the contracting parties, in order to maintain economic contractual equilibrium of the contract. To do so, the function of the causation theory should be analysed in a comparative analytical approach with the Chronopost's decision to illustrate the Palestinian legislative deficiencies. It will also show the
\end{abstract}

* Ph.D. Candidate, Faculty of Law, University of Malaya. Email: advosama@outlook.com.

** Senior Lecturer, Faculty of Law, University of Malaya. Email: izuramas@um.edu.my.

*** Senior Lecturer Faculty of Law, University of Malaya. Email:pardismoslemzadeh@um.edu.my.

**** Associate Professor at Faculty of Law, Arab American University, Palestine. 
need for adopting the French judicial approach, which will establish a general rule that any arbitrary clause that contravenes the essential obligation of the contract is considered to be unwritten, regardless of the nature or the subject matter of the contract.

Keywords: causation theory, Chronopost's decision, economic contractual equilibrium, Palestinian civil code draft, annulling arbitrary conditions.

\title{
PERANAN BARU TEORI PENYEBABAN UNTUK MENCAPAI KESEIMBANGAN EKONOMI KONTRAK: MEMANSUHKAN SYARAT-SYARAT ARBITARI
}

\begin{abstract}
ABSTRAK
Frasa "sesiapa yang menyatakan kontraktual, menyatakan keadilan" (qui dit contractuel dit juste) tidak mencerminkan sepenuhnya kebenaran sebenar realiti sekarang, di mana frasa tersebut penuh dengan keraguan, disebabkan kontrak tidak selalunya menghasilkan obligasi-obligasi yang adil. Dalam hal ini, badan kehakiman Perancis menyedari bahawa ketiadaan keadilan di dalam kontrak mungkin disebabkan oleh kebebasan kontraktual yang diberikan kepada pihak-pihak berkontrak. Oleh itu, idea Cumutative Justice di dalam kontrak dibangunkan, sebagai contoh, ia dianggap sebagai salah satu daripada aplikasi yang paling penting di dalam keputusan Chronopost. Walau bagaimanapun, kesetaraan hak dan obligasi di dalam Deraf Kod Sivil Palestin hanya wujud dalam bentuk maya, tanpa apa-apa kandungan yang menyumbang kepada pencapaian kesetaraan antara hak dan obligasi di dalam kontrak. Kertas ini berusaha untuk membuktikan bahawa peruntukan teori penyebaban di dalam Deraf Kod Sivil Palestin boleh digunakan sebagai satu cara yang berkesan untuk mencapai keadilan kontraktual di antara pihak-pihak berkontrak, supaya keseimbangan ekonomi kontrak dikekalkan. Untuk mencapainya, fungsi teori penyebaban perlu dianalisa dengan menggunakan pendekatan analitikal komparatif dengan keputusan Chronopost, untuk memberi gambaran kekurangan di dalam legislatif Palestin. Ia juga akan menunjukkan keperluan untuk mengikuti pendekatan kehakiman Perancis, yang akan menubuhkan satu peraturan umum bahawa mana-mana klausa arbitrari yang melanggar kewajipan penting kontrak, akan dianggap tidak bertulis, tanpa mengira sifat atau subjek kontrak tersebut.
\end{abstract}


Kata kunci: teori penyebaban, keputusan Chronopost, keseimbangan ekonomi kontrak, deraf kod sivil Palestin, memansuhkan syarat-syarat arbitrari.

\section{INTRODUCTION}

The Palestinian Draft Civil Code "PDCC"1 adopted the causation theory in Articles $135,{ }^{2} 136,{ }^{3} 137^{4}$ and $138,{ }^{5}$ as an essential element for the conclusion of the contract to be valid, where the consent of the parties is not the only element for the conclusion of the contract. ${ }^{6}$ Nevertheless, the conventional content of the causation theory in the PDCC stipulated that for the cause of the obligation to be valid, three conditions must meet: the existence of the cause, ${ }^{7}$ its validity,${ }^{8}$ and legitimacy. ${ }^{9}$ This was adopted by the French Civil Code of 1804 in

1 (Hereinafter 'PDCC').

2 Article 135 of the PDCC states: "An obligation does not rise if it does not have a cause and as such the contract is null".

3 Article 136 of the PDCC states: "1-Every obligation is supposed to have a real cause, even if it is not mentioned; 2- It is, also, supposed that the mentioned cause for the contract is the real cause unless proven otherwise".

4 Article 137 of the PDCC states: "1- A contract is considered null if its cause is illegitimate; 2- A contract's cause is considered illegitimate if its motive is against the public order or morals".

5 Article 138 of the PDCC states: "1- Every contract is supposed to have a legitimate cause even if the cause for the contract is not mentioned; however, if it has been proved that the cause is illegitimate then, the contract in question is considered null; 2- Nonetheless, in bilateral contracts, it is not permissible for a contracting party, who has an illegitimate motive, to invoke the nullity of the contract unless the other party is aware of such an illegitimate motive".

6 Article 1108 of the French Civil Code of 1804 states: "Four conditions are essential to the validity of an agreement: 1 - The consent of the party who binds himself; 2- His capacity to contract; 3 - A certain object forming the matter of the contract; 4- A lawful cause in the bond". In the same regards, see Articles 74-138 of the PDCC.

7 See Article 135 of the PDCC.

8 See Article 136 of the PDCC.

9 See Article 137 of the PDCC. 
Article 1131, which states that: "An obligation without a cause, or upon a false cause, or upon an unlawful cause, can have no effect". ${ }^{10}$

However, Article 135 of the PDCC represents clearly that the Palestinian legislature adopted the final cause (cause finale) in determining the concept of the causation theory. ${ }^{11}$ Nonetheless, Article 137 of the PDCC declares that the Palestinian legislature adopted the impulsive cause in determining the concept of the causation theory. ${ }^{12}$ In fact, the PDCC adopted the concept of both conventional and modernistic theory in determining the content of the causation theory, ${ }^{13}$ i.e. the Palestinian legislature adopted the idea of ambivalent cause in determining the content of the causation theory.

Thus, within the scope of the PDCC, the causation theory has two requisite functions which are; the equivalence of rights and obligations and the interdependence of obligations. However, the French judiciary in the later part of the last century has shown an

10 The French Civil Code of 1804 is considered as one of the main bases of the PDCC. See the Official Explanatory of the Palestinian Civil Code Draft (hereinafter 'OEPDCC'), unpublished manuscript, at 25-26.

11 The final cause is the abstract direct purpose that the obligor wants to achieve by obliging himself. This definition has been referred to by many terms such as direct cause or abstract cause or objective cause; nevertheless, the term 'cause' of obligation is the term which is commonly used nowadays. See Ibrahim Ashmawi, Causation Theory and Contractual Justice (Cairo: Dar Alnahdah Alearabiah, 2008), 22-26.

12 The impulsive cause is the personal motive that led the contracting party to conclude the contract. This definition (impulsive cause) has been referred to by many terms such as concrete cause (cause concrète), or subjective cause (cause subjective), or indirect cause (cause lointaine); nonetheless, the term 'cause' of the contract (cause du contrat) is the term which is commonly used nowadays. See Jacques Flour, Jean-Luc Aubert, Eric Savaux, Droit Civil, Les Obligations, 1. L'acte juridique, Sirey (Paris: Dalloz, 2013), 189. Jacques Ghestin, Traité de droit civil, Les obligations, La formation du contrat (Paris: Librairie L.G.D.J, 1993), 829-830.

13 This Trend is commonly used in most of Arabian countries' civil codes, for example, see Articles (194-201) of the Lebanese Civil Code, Articles (165-166) of the Jordanian Civil Code, Articles (176-177) of the Kuwaiti Civil Law and Articles (136-137) of the Egyptian Civil Code. See Mohammad Abdaa, Theory of Causality in Civil Law, A Comparative Study (Beirut: Al-Halabi Legal Publications, 2004), 104. 
effective role for the theory of causation in the protection of the contract itself. This is done by using causation as a supportive means of protecting the economic contractual equilibrium of the contract, whenever such is necessary. All of this will be analysed in the framework of the provisions of the causation theory in the PDCC to ensure that this mechanism performs its legal function. Nevertheless, determining the function of the causation theory requires this issue to be addressed first.

\section{THE CONVENTIONAL FUNCTION OF THE CAUSATION THEORY IN THE PDCC}

In addition to protecting the public interest of society, this theory has another function, where the objective concept of the cause allows for monitoring the matter of the existence of the cause. ${ }^{14}$ Thereby, it contributes to the protection of the individual interests of the contracting parties, who are waiting for the corresponding obligations for which each has given. Thus, the verification of the equivalence of rights and obligations is seen as the most important role in the conventional function of the causation theory in the PDCC. However, the function of the causation theory does not stop there. Through the idea of the interdependence of obligations, for which the cause is considered a basis, many judicial provisions that also have an effective role in the achievement of an economic contractual equilibrium can be justified. These include termination (resolution of the contract) (la résolution $)^{15}$ and exception for non-performance (l'exception d'inexécution) provisions. ${ }^{16}$

14 See footnote no: 10.

15 Article 170 of the PDCC states: "1- In bilateral contracts (contrats synallagmatiques) if one of the parties does not perform his obligation, the other party may, after serving a formal summons on the debtor, demand the performance of the contract or its rescission, with damages, if due, in either case. 2- The judge may grant additional time to the debtor, if it is necessary as a result of the circumstances. The judge may also reject an application for rescission when the part of the contract which the debtor has failed to perform is of little importance in comparison with the obligation in its entirety".

16 Article 149 of the PDCC states: "When, in the case of bilateral contracts, correlative obligations are due for performance, either of the contracting 


\section{The Equivalence of Rights and Obligations}

The essential function of the causation theory is to protect the contracting parties themselves. This is achieved only by activating the conditions of the existence and validity of the cause. This situation has pushed the Palestinian legislature in the PDCC to assert that the existence of the will of the committed party is not enough for the establishment of an obligation, but that it also requires that this will has a cause directing the will of the contracting party. ${ }^{17}$ Thus, the contracting party can be released from preforming its obligation if it is found to be without a cause.

However, such protection cannot be achieved by the existence of the cause only, since in the field of determining the corresponding obligation, there must be an objective criterion within the contract. In order to achieve such protection, the manifestations of which are the equivalence between the corresponding performances. ${ }^{18}$ Besides that, each contracting party wants the equation between what it gives versus what it takes. Furthermore, it is clear that there is an imbalance in the equivalence of the corresponding performances when individuals are left to determine the values of their own performances with the absence of good faith in dealing which contradicts the principle of contractual justice.

Therefore, the French legal jurist Maury was the first to demand the idea of equivalence of performances as part of the causation theory..$^{19}$ Maury defined the cause as a justification for transferring the financial value from one person to another; also, he believes that the cause for bilateral contracts is the economic counterpart, as he concluded that there is no cause unless there was an economic counterpart (n'est cause que ce qui est équivalent).$^{20}$ This approach was adopted by the French legal jurist Louis Lucas, who made the cause to be represented in the economic value determined by the contracting

parties may refrain from the performance of his obligation, if the other party does not perform his obligation".

17 See the OEPDCC, at 169-170.

18 See Gabriel Marty, Pierre Raynaud, and Philippe Jestaz, Droit Civil, Les Obligations, Vol. 1. (Paris: Sirey, 1989), P 210.

19 See Or'ara Assali, "The Contractual Balance at the Conclusion of the Contract" (PhD Diss., University of Algeria 1, 2015), 139.

20 See Demarche Azouz, "Contractual Balance" (PhD Diss., University of Abu Bakr Belqayd, 2014), 180. 
parties in relation to the matter of the equivalence between the corresponding obligations. In his view, as a general rule, the decisions of the contracting parties are considered to be sufficiently equivalent, while lesion ${ }^{21}$ and fraudulent misrepresentation ${ }^{22}$ are exceptions to this rule. $^{23}$

Here, and according to the Palestinian legislature's explanation of the content of the validity of the cause in the OEPDCC, it is found that the idea of the equivalence of rights and obligations only exists in a virtual form, without any content that actually contributes to the achievement of the equivalence between rights and obligations in contracts. ${ }^{24}$ Nevertheless, according to the conventional perception of what is stated in the PDCC and although there is a clear link between the existence of the cause and its validity and the equivalence between the corresponding performances, these concepts should not be integrated. Not integrating such concepts is due to the fact that the obligation of a contracting party has a cause as soon as the counterparty presented a real corresponding obligation, ${ }^{25}$ even if this corresponding

21 Article 128 of the PDCC ruled: "If the obligations of one of the contracting parties are out of all proportion to the advantages that he obtains from the contract or to the obligations of the other contracting party, and it is established that the party who has suffered the prejudice entered into the contract only as a result of the other party exploiting his obvious levity of character or his unbridled passion, the judge may, at the request of the party so prejudiced, annul the contract or reduce the obligations of such party".

22 Article 124 of the PDCC states: "1- A contract may be declared void on the grounds of fraudulent misrepresentation, when the artifices practiced by one of the parties, or by his representative are of such gravity that, but for them, the other party would not have concluded the contract. 2Intentional concealment on the part of one of the parties as to a fact or as to the accompanying circumstances constitutes fraudulent misrepresentation if it can be shown that the contract would not have been concluded by the other party had he had knowledge thereof".

23 See Ghestin, Traité de droit civil, Les obligations, La formation $d u$ contrat, 836-837.

24 The content of the condition of validity of the cause in the PDCC is limited to the case of simulated cause (la cause simulée) and the erroneous cause. See the OEPDCC, at 170.

25 See Article 136 of the PDCC. 
obligation is small in its value, compared to the other corresponding obligation. $^{26}$

Consequently, the mere simple imbalance of economic equivalence between the corresponding obligations does not result in the absence of the cause. However, in order to say that, there must be a real imbalance of the corresponding obligation in which the corresponding obligation is negligible or does not exist. ${ }^{27}$ Nonetheless, it should be noted that even if the corresponding obligation is trivial, the provisions of the causation theory in the PDCC do not provide any solution to remedy this economic contractual imbalance. In such case, the disadvantaged party may request the court to revoke the contract based on the provision for lesion if its conditions are met. ${ }^{28}$

\section{The Interdependence of Obligations}

The Roman law was not acquainted with the idea of the interdependence of obligations, where the obligation of each party has risen independently of the obligation of the other party. Consequently,

26 See the OEPDCC, at 170.

27 See François Terré, Philippe Simler, Yves Lequette, Droit civil, Les obligations (Paris: Dalloz, 2013), 283. The French judiciary settled on this status for a long time, refusing to estimate the equivalence of the corresponding performances based on the causation theory. An example of this, the lessor obligation to maintain the leased property remains valid, even if the rent is insufficient, justified his position that this menaces the stability of dealings, and violates the rule that lesion provisions are taken in exceptional cases. In this regard, Article 621 of the PDCC ruled: "1The lessor is bound to maintain the leased property in the state in which it was at the time of delivery. He must make, during the continuance of the lease, all repairs which may become necessary, except lessee's repairs. The lessor is also bound to do such plastering and white-washing of the roofs as may be necessary, and to clear wells, cesspools and drains. 2- The lessor is responsible for charges and taxes due on the leased property. The lessor is also responsible for the cost of water, if it is supplied for a lump sum, but the lessee is responsible if it is supplied by meter. The costs of electricity, gas and of other requirements for personal use are payable by the lessee. 3- The above rules only apply in the absence of agreement to the contrary". See Rémy Cabrillac, Droit des obligations (Paris: Dalloz, 2014), 60.

28 See Article 128 of the PDCC. 
the refrain of one of the parties from implementing its obligation would not have allowed the other party to terminate the contract. But, with the advent of Canon Law, bilateral contracts were closely linked, not only during the pre-contracting phase, but also in the implementation phase, whereby each obligation's cause must be in the corresponding obligation of the other party which is associated with it. ${ }^{29}$

The Canonists are the first to deduce the dual function of the causation theory -that is, the economic function, which is based on the idea of interdependence of obligations in addition to a moral function that is based on the necessity of protecting society. ${ }^{30}$ Moreover, they formulated the following principle: "non servandi fidem non est fides servanda", ${ }^{31}$ i.e., if one of the contracting parties fails to fulfill his obligation, the other party's obligation will be eliminated. ${ }^{32}$

However, the dedication of the cause as an ideal means of protecting contractual wills appears to be the legal basis for interpreting some of the legal effects of the contract. As such, the cause for the contracting party's obligation in bilateral contracts is represented in the existence of the obligation of the other party. This situation assumes that there is a correlation between the two obligations. Thus, it is allowed for the contracting party to suspend the execution of its obligation or to be released from it permanently if the other party refuses to implement the obligations on its part. In other words, the causation theory justifies the establishment of legal situations that contribute to the protection of the interests of the contracting party itself in a manner intended to establish economic contractual equilibrium such as the provisions for termination (resolution of the contract) (la résolution) and exception for non-performance (l'exception d'inexécution).

29 See Terré, Simler, Lequette, Droit civil, Les obligations, 270.

30 See Christian Larroumet, Droit civil: Les Obligations, Le Contrat (Paris: Économica, 1996), 422.

31 See Assali, "The Contractual Balance at the Conclusion of the Contract", 141. Rafael Sanchez Domingo, "Traditio: Rite, Symbol and Title in the Land Transmission," GLOSSAE: European Journal of Legal History 12 (2015): 766.

32 "on n'a pas à tenir sa parole au regard de la personne qui ne tient pas la sienne". See Henri Mazeaud, Léon Mazeaud, François Chabas, Leçons de droit civil, tom II, premier volume, les obligations (Paris: Montchrestien Delta, 2000), 264. 


\section{The Exception for Non-Performance (l'exception d'inexécution) Provisions}

The French judiciary, subject to the provisions of the Civil Code, ${ }^{33}$ has settled that where there is a correlative obligation, ${ }^{34}$ the debtor in one of these obligations is entitled to refrain from implementing his obligation until the other debtor performed his obligation. ${ }^{35}$ In this regard, the Palestinian legislature ruled that:

"In the case of bilateral contracts, correlative obligations are due for performance, either of the contracting parties may refrain from the performance of its obligation, if the other party does not perform its obligation". ${ }^{36}$

In this sense, the exception for non-performance (exception non adimpleti contractus), ${ }^{37}$ is defined as:

33 Article 1184 of the French Civil Code of 1804 states: "1- A condition dissolutory is always intended in synallagmatic contracts, for the case in which one of the two parties shall not satisfy his engagement. 2- In this case the contract is not dissolved absolutely, the party towards whom the engagement has not been performed, has his election either to compel the other to performance of the agreement where it is possible, or to demand the dissolution thereof with damages and interest. 3- The dissolution may be demanded by law, and a delay may be granted to the defendant according to circumstances".

34 "l'exception d'inexécution ne peut être invoquée qu'en présence de deux obligations interdépendantes;...". "en toute hypothèse, l'inexécution qu'une partie est fondée à opposer, en vertu de l'exceptio non adimpleti contractus, doit être proportionnée à celle de son cocontractant;....". See "French Court of Cassation, civil room 1, public sitting of Friday 15 May 2015, no of appeal: 14-16256," légifrance, le service public de la diffusion du droit, accessed January 14, 2019,

https://www.legifrance.gouv.fr/affichJuriJudi.do?oldAction=rechExpJuri Judi\&idTexte=JURITEXT000030602422\&fastReqId=969628892\&fastP os $=175$.

35 See Azouz, "Contractual Balance", 183.

36 See Article 149 of the PDCC.

37 The exception for non-performance, as its Latin formulation suggests, does not refer to Roman law, since the Romans did not know the exception for non-performance as a general theory, even if they allowed the contracting party in bilateral contracts to refrain from the performance of its obligation if the other party did not fulfill what it had pledged, it was done in accordance with other legal rules. See Anwar Sultan, Sources of 
"A legal permission, under which the contracting party is entitled to refrain from performing its due obligation in bilateral contracts as a means of pressure on the other party who refrains from implementing its due obligation", ${ }^{38}$

It is thus a mechanism that either paves for the implementation or termination of obligations. ${ }^{39}$ However, Article 149 of the PDCC stipulated three conditions that must be met to invoke the exception for non-performance which are: the contract must be bilateral, the corresponding obligation is due and that one of the contracting parties does not perform its obligation. ${ }^{40}$ Moreover, the OEPDCC stipulated another condition which is that the principle of good faith should be observed when adhering to the exception for non-performance, ${ }^{41}$ i.e. the contracting party should not be arbitrary in the use of this mechanism. ${ }^{42}$

Therefore, the legal jurists differed with respect to determining the legal basis for adhering to the exception for non-performance by

Commitment in Civil Code, A Comparative Study with Islamic Jurisprudence (Amman: Dar Al-Thaqafa for Publishing and Distribution, 2011), 266. Jusztinger Janos, "Transfer of Property via Sale in Ancient Rome in Light of the New Civil Code," Jura: A Pecsi Tudomanyegyetem Allam- es Jogtudomanyi Karanak tudomanyos lapja 2016, no. 2 (2016): 75. Claudia Mejias Alonzo, "Exceptio non Adimpleti Contractus and Its Establishment in Chilean Civil Code," Revista Chilena de Derecho 40, no. 2 (May-August 2013): 407.

See Amjad Mansour, The General Theory of Obligations, Sources of Commitment, A Study of the Jordanian, Egyptian and French Civil Codes, the AL-Majallah AL-Ahkam AL-Adliyyah and Islamic Jurisprudence with the Judicial Applications of the Cassation Courts (Amman: Dar AlThaqafa for Publishing and Distribution, 2009), 220.

39 See Jalal Ibrahim, Sources of the Obligation (Cairo: Dar Alnahdah Alearabiah, 2011), 285-286.

40 See Article 149 of the PDCC.

41 See the OEPDCC, at 184.

42 Which is not necessary to mention here, since Article 148 of the PDCC requires that: " 1 - The contract shall be executed in accordance with what it has included and, in a manner, consistent with what is required by good faith. 2- The contract shall not obligate the contracting parties to what is stated therein, but shall also include what is required by law, custom and the nature of the act. 3- In contracts prepared on models to unify the organization of contractual relations, the conditions added to those models shall apply to the original conditions, even if the latter are not written". 
attributing it to different legal bases. These include fair dealing, the principle of good faith or the causation theory. ${ }^{43}$ Each of them has his own justifications and established reasonable grounds that support his beliefs. Nevertheless, the majority of legal jurists and the judiciary attribute this mechanism to the causation theory in bilateral contracts. ${ }^{44}$ Thus, the role played by the exception for non-performance is not hidden in the embodiment of the idea of contractual equilibrium on the basis that it is not fair to oblige the ones who lost the benefit for which they contracted by not relying on the legal means to be able to fulfill it.

\section{The Termination (resolution of the contract) (la résolution) Provisions}

The idea of interdependence of obligations in bilateral contracts was emphasized by the Canon Law, on the basis of which the idea of termination was created for non-enforcement. This is meant as a protection for the party that contracts in good faith, as the exception for non-performance was limited in providing the perfect protection for this party. ${ }^{45}$ In this sense, the Palestinian legislature ruled that:

"1- In bilateral contracts (contrats synallagmatiques) if one of the parties does not perform its obligation, the other party may, after serving a formal summons on the debtor, demand the performance of the contract or its rescission, with damages, if due, in either case...". 46

43 See Abd Al-Razzaq Al-Sanhuri, Illustration of Updated Civil Law (Beirut: Al-Halabi Legal Publications, 1998), 731.

44 Such as Ghestin, Weill and Terré. Abdaa, Theory of Causality in Civil Law, 132-133. See also "French Court of Cassation, civil room 2, public sitting of Thursday 18 April 2013, no of appeal: 12-17598, 12-17599, 1217600, 12-17601, 12-17604, 12-17606, 12-17607," légifrance, le service public de la diffusion du droit, accessed January 14, 2019, https://www.legifrance.gouv.fr/affichJuriJudi.do?oldAction=rechExpJuri Judi\&idTexte $=$ JURITEXT000027335802\& fastReqId $=896280111 \&$ fastP os $=37$.

45 See Azouz, "Contractual Balance", 184. Anne Asselin, "Lay Ecclesial Ministers and Removal from Office: Seeking Justice and Fairness," Jurist (Catholic University of America) 73, no. 1 (2013): 193.

46 See Article 170 of the PDCC. 
Subsequently, the termination is the penalty for a breach by one of the contracting parties of its obligation, so that the other party is released from the obligations it incurs under the contract. However, the right of the contracting party who is requesting the termination of the contract is subjected to the following conditions: the contract must be bilateral, the obligation of one of the contracting parties is not being fulfilled, and that the party who is requesting the termination of the contract does not breach its obligation. ${ }^{47}$

Therefore, the legal jurists and the French judiciary differed in determining the legal basis for the idea of the termination of the contract. However, many of them believe that the basis for the termination of the contract lies in the idea of the interdependence of obligations, the legal basis of which lies in the causation theory. ${ }^{48} \mathrm{In}$ this regard, the Palestinian legislature clearly stated in the OEPDCC that the termination of the contract in accordance with Article 170 of the PDCC found its legal basis in the causation theory. ${ }^{49}$

It can be concluded from the above that the application of the causation theory during the conclusion phase and the consequent legal mechanisms will maintain a considerable proportion of contractual equivalence between the obligations in the PDCC and will, thus, contribute to ensure a broad protection of the contracting parties.

47 See the OEPDCC, at 205-206.

48 See Mansour, The General Theory of Obligations, Sources of Commitment, 202. See also "French Court of Cassation, civil room 1, public sitting of Thursday 3 March 2011, no of appeal: 10-13478," légifrance, le service public de la diffusion du droit, accessed January 15, 2019 ,

https://www.legifrance.gouv.fr/affichJuriJudi.do?oldAction=rechExpJuri Judi\&idTexte=JURITEXT000023666180\&fastReqId $=368188122 \&$ fastP os $=47$.

"French Court of Cassation, commercial room, public sitting of Tuesday 1 December 2009, no of appeal: 08-14794," légifrance, le service public de la diffusion du droit, accessed January 15, 2019, https://www.legifrance.gouv.fr/affichJuriJudi.do?oldAction=rechExpJuri Judi\&idTexte=JURITEXT000021389426\&fastReqId=1919398870\&fast Pos $=54$.

49 See the OEPDCC, at 205. 


\section{THE CAUSATION THEORY AS A MEANS OF RESTORING THE ECONOMIC CONTRACTUAL EQUILIBRIUM OF THE CONTRACT: CHRONOPOST'S DECISION}

The legal jurisprudence indicates that the corresponding obligation should not be trivial, ${ }^{50}$ but must have value and importance; however, in an economic sense, the contract is defined as an exchange of values as it is the exchange of satisfaction..$^{51}$ More clearly, the basis of the binding force of the contract should not be sought in the principle of will autonomy, but in the notion of contractual justice (la justice contractuelle). This notion stipulates that only agreements that are free of an obvious imbalance between the corresponding rights and obligations are legally valid. ${ }^{52}$

In this sense, the significant decision issued on 22 October 1996 by the French Court of Cassation in the Chronopost case strongly expresses the significance of (la justice contractuelle). ${ }^{53}$ Such significance is closely associated with a judicial trend which, for several years, has shown particular interest in the idea of economic contractual imbalance. This includes the decision issued on 03 July

50 See Ashmawi, Causation Theory and Contractual Justice, 97.

51 See Sabine Tsuruda, "Contract, Power, and the Value of Donative Promises," South Carolina Law Review 69, no. 2 (Winter 2017): 480. David Sandomierski, "Tension and Reconciliation in Canadian Contract Law Casebooks," Osgoode Hall Law Journal 54, no. 4 (2017): 1214. Chapin F. Cimino, "Doing Deals with Aristotle - Today," Seattle University Law Review 41, no. 1 (Fall 2017): 235.

52 See Todd D. Rakoff, "The Five Justices of Contract Law," Wisconsin Law Review 2016, no. 4 (2016): 740-741. Dmitry Poldnikov, "Origins of General Concept of Contract in Western European Legal Science," Journal on European History of Law 7, no. 2 (2016): 58. Robin Kar, "Contract as Empowerment," University of Chicago Law Review 83, no. 2 (Spring 2016): 815.

53 See "French Court of Cassation, commercial room, public sitting of Tuesday 22 October 1996, no of appeal: 93-18632," légifrance, le service public de la diffusion du droit, accessed January 16, 2019, https://www.legifrance.gouv.fr/affichJuriJudi.do?oldAction=rechExpJuri Judi\&idTexte=JURITEXT000007035966\&fastReqId=232986072\&fastP os $=1$. 
1996 by the French Court of Cassation in Piller's case. ${ }^{54}$ However, this trend was welcomed by a great part of the French legal jurisprudence, especially in view of the fact that the French Court of Cassation, in its aforementioned provisions, was careful not to allow a party to go beyond the use of its economic power by imposing unfair conditions on the other party. ${ }^{55}$ In addition, these provisions relate to the probable concept of the contract based on the idea of Commutative Justice. Thus, it can be argued that the basis of justice in contracts is the actual equality and the real and fair equivalence between the performances of the contracting parties. ${ }^{56}$

Although the Palestinian legislature has inserted the cause of obligation into the very idea of the contract itself, the study of the contemporary development of the causation theory shows that what the Palestinian legislature has stated is somewhat minor and contradictory at the same time. Minor, that is, to the extent that the essential role of the cause as a means for achieving contractual justice under the general theory of contracts is excluded. It is also contradictory, that is, by reviewing the general development of contract law, which has not ceased for some time to regularly use some special mechanisms (private laws), ${ }^{57}$ trying to provide the minimum contractual justice requirements. However, they have not yet resorted to legislate the contractual justice mechanisms on which the cause of the obligation

54 See "French Court of Cassation, civil room 1, public sitting of Wednesday 3 July 1996, no of appeal: 94-14800,' légifrance, le service public de la diffusion du droit, accessed January 16, 2019, https://www.legifrance.gouv.fr/affichJuriJudi.do?oldAction=rechExpJuri Judi\&idTexte=JURITEXT000007036953\&fastReqId=934404352\&fastP os $=18$.

55 See Yann Aubin; Tim Portwood, "Les Clauses Reciproques D'Abandon De Recours et Garanties Contre Les Recours des Tiers," International Business Law Journal 2001, no. 6 (2001): 684.

56 "le juste dans les contrats consiste en une certaine égalité". See Carlos Pizarro Wilson, "Notas Criticas sobre el Fundamento de la Fuerza Obligatoria del Contrato - Fuentes e Interpretacion del Articulo 1545 del Codigo Civil Chileno," Revista Chilena de Derecho 31, no. 2 (MayAugust 2004): 227.

57 Such as the Palestinian Labour Law No. 7 of 2000, the Palestinian Law of Insurance No. 20 of 2005, the Palestinian Law of Concerning Consumer Protection No. 21 of 2005, etc., while the Palestinian Civil Code, which is the general theory of contract law, is still a draft. 
was based. ${ }^{58}$ Nevertheless, the French judiciary has recently shown the importance of the causation theory as a tool or legal means to protect the contract itself, and not just to protect the contracting parties. ${ }^{59}$ Therefore, and in order to achieve the purpose of this section, this article will analyse the segments of the famous French decision as follows.

\section{The Facts of Chronopost Decision}

The Commercial Room of the French Court of Cassation has based the theory of cause as a basis for cancelling arbitrary or abusive conditions, based on the facts of the case. In this case, the Chronopost Expressway Company guarantees the transfer of postal parcels containing Banchereau's participation in a tender for the supply of meat. On two consecutive occasions, the postal parcels arrived late, which deprived Banchereau from entering the tender, ${ }^{60}$ while Chronopost ensured the accuracy and rapidity of its performance of this postal service. Moreover, Chronopost was committed to delivering Banchereau's postal parcels within a specified period agreed upon by the contracting parties. ${ }^{61}$

58 In addition, the judiciary, law and jurisprudence are implicitly aware that the assumption assumed by the authors of the Civil Code that the contracting parties are equal and free to contract is merely an illusion. See Marc Mignot, "De la Solidarité en Général, et du Solidarisme Contractuel en Particulier ou Le Solidarisme Contractuel a-t-il un Rapport Avec la Solidarité?" Revue de la Recherche Juridique-Droit Prospectif 4 (2004): 2153-2197.

59 See Eric Fokou, "La Notion d'Economie du Contrat en Droit Francais et Quebecois," Revue Generale de Droit 46, no. 2 (2016): 350.

60 See, "Limitation and Exclusion Clauses in CISG Contracts," Nordic Journal of Commercial Law 2017, no. 2 (2017): 282.

61 "attendu qu'en statuant ainsi alors que, spécialiste du transport rapide garantissant la fiabilité et la célérité de son service, la société Chronopost s'était engagée à livrer les plis de la société Banchereau dans un délai déterminé,..". See "French Court of Cassation, commercial room, public sitting of Tuesday 22 October 1996, no of appeal: 93-18632," légifrance, le service public de la diffusion du droit, accessed January 17, 2019, https://www.legifrance.gouv.fr/affichJuriJudi.do?oldAction=rechExpJuri Judi\&idTexte=JURITEXT000007035966\&fastReqId=232986072\&fastP os $=1$. 
Nevertheless, Chronopost failed to implement its obligation, which deprived Banchereau of the opportunity to enter the tender. Upon this failure, Banchereau filed a lawsuit against Chronopost, demanding compensation for the damages it suffered. ${ }^{62}$ Accordingly, Chronopost replied in its plea that there was an included condition in the contract. This condition determined the amount of compensation for the delay in delivering the postal parcels only by the amount that represents the difference between the price of regular and express post (liability limiting clause) ${ }^{63}$ In other words, Chronopost inserted in the contract a condition that limits its liability if it breaches its obligations.

Consequently, the Rennes Court of Appeal on 30 June 1993 ruled that:

"While Chronopost had failed to perform its obligation to deliver the postal parcels containing Banchereau's participation in a tender before midday on the day following their posting, it had

62 "attendu, selon l'arrêt infirmatif attaqué, que la société Banchereau a confié, à deux reprises, un pli contenant une soumission à une adjudication à la société Chronopost, venant aux droits de la société SFMI; que ces plis n'ayant pas été livrés le lendemain de leur envoi avant midi, ainsi que la société Chronopost s'y était engagée, la société Banchereau a assigné en réparation de ses préjudices la société Chronopost ; que celle-ci a invoqué la clause du contrat limitant l'indemnisation $d u$ retard au prix du transport dont elle s'était acquittée;....". See "French Court of Cassation, commercial room, public sitting of Tuesday 22 October 1996, no of appeal: 93-18632," légifrance, le service public de la diffusion du droit, accessed January 17, 2019, https://www.legifrance.gouv.fr/affichJuriJudi.do?oldAction=rechExpJuri Judi\&idTexte=JURITEXT000007035966\&fastReqId=232986072 \&fastP os $=1$.

63 "une autre clause du contrat stipule que si la société Chronopost ne respecte pas son engagement, l'indemnisation qu'elle doit à son cocontractant correspond au prix du transport dont celui-ci s'était acquitté...". "French Court of Cassation, commercial room, public sitting of Tuesday 22 October 1996, no of appeal: 93-18632," légifrance, le service public de la diffusion du droit, accessed January 17, 2019, https://www.legifrance.gouv.fr/affichJuriJudi.do?oldAction=rechExpJuri Judi\&idTexte=JURITEXT000007035966\&fastReqId $=232986072 \&$ fastP os $=1$. 
nevertheless not committed gross negligence debarring the limitation of liability in the contract". ${ }^{64}$

However, on 22 October 1996, the French Court of Cassation rescinded the decision of Rennes Court of Appeal. It, thus, ruled that while Chronopost is specialised in fast transportation and the guaranteed accuracy and rapidity of its service, it had pledged to deliver the postal parcels containing Banchereau's participation within a specified time. In addition, it had also failed to perform this essential obligation. As such, the limiting clause of liability of Chronopost contradicted the effect of the pledge given, and had to be considered as unwritten, thus, deemed null and void. On this basis, the Court of Appeal violated the provisions of Article 1131 of the French Civil Code of $1804 .^{65}$

Hence, this decision of the French Court of Cassation was the subject of a renewal that drew the attention of the French legal jurists to adopt the causation theory as a mechanism for restoring contractual equivalence as discussed below.

\section{The Essential Obligation and the Absence of the Cause}

The Palestinian legislature, similar to the French legislature, stated that each obligation in bilateral contracts has a corresponding obligation in the contract. ${ }^{66}$ However, the French Court of Cassation has ruled

64 "l'arrêt retient que, si la société Chronopost n'a pas respecté son obligation de livrer les plis le lendemain du jour de l'expédition avant midi, elle n'a cependant pas commis une faute lourde exclusive de la limitation de responsabilité du contrat;...”. See Maria Natalia Mato Pacin, "Content Control of Standard Terms in Business-to-Business Contracts in Comparative and European Law," Cuadernos de Derecho Transnacional 7, no. 2 (October 2015): 224.

65 "la clause limitative de responsabilité du contrat, qui contredit la portée de l'engagement pris, devait être réputée non écrite". Stephanie Ghozlan, "The Concept of Essential Obligation under the Control of Abusive Clauses: The Study of French and Quebec Legal Systems," Revue Juridique Themis 49, no. 2 (2015): 411. Oana Elena Gheorghe, "Theoretical Considerations and Practical Aspects on the Institution of Guilt within the Contractual Liability and the Limitation of the Contractual Liability," Journal of Law and Public Administration 4, no. 7 (2018): 47.

66 See the OEPDCC, at 169. 
previously that: ${ }^{67}$ the abusive clause in the contract does not affect the nature or substance of the lessor's obligation to put the leased property at the disposal of the lessee, which excludes any possibility of annulment of the abusive clause on the basis of the partial absence of the cause of the obligation (l'absence partielle de cause).$^{68}$

Subsequently, the French Court of Cassation has retracted its previous position under the influence of Article 1131 of the French Civil Code of 1804 in a progressive manner, ${ }^{69}$ until the decision of the French Court of Cassation on the case of Chronopost was ruled. The French Court of Cassation considered that the payment paid for sending the postal parcels means in return that the obligation of Chronopost is to deliver these postal parcels within the specified time. ${ }^{70}$

In other words, the essential obligation of Chronopost is not only to deliver the postal parcels, but also to deliver them on the agreed date specified in the contract, since it is a matter of rapid transportation. Otherwise, Banchereau would not have accepted a higher payment than it could have paid for delivering the postal parcels in the normal post. Thus, Chronopost has breached this essential obligation (not delivering the postal parcels on the agreed date specified in the contract) which represents the essence of this contract. Therefore, the interest or utility that Banchereau was waiting to achieve from paying a price to Chronopost was wasted, since the delivery was made but later than the agreed date; hence, part of Chronopost's obligation would be absent, namely, delivering the postal parcels on the agreed date specified in the

67 "French Court of Cassation, commercial room, public sitting of Monday 3 February 1975, no of appeal: 73-13564," légifrance, le service public de la diffusion du droit, accessed January 17, 2019,

https://www.legifrance.gouv.fr/affichJuriJudi.do?oldAction=rechExpJuri Judi\&idTexte=JURITEXT000006993792\&fastReqId=395473969\&fastP os $=3$.

68 See Terré, Simler, Lequette, Droit civil, Les obligations, 335-337.

69 "French Court of Cassation, civil room 1, public sitting of Wednesday 19 December 1990, no of appeal: 87-17586," légifrance, le service public de la diffusion du droit, accessed January 17, 2019,

https://www.legifrance.gouv.fr/affichJuriJudi.do?oldAction=rechExpJuri Judi\&idTexte=JURITEXT000007100362\&fastReqId=1857206400\&fast Pos $=4$.

70 See Ghozlan, "The Concept of Essential Obligation under the Control of Abusive Clauses: The Study of French and Quebec Legal Systems," 412. 
contract (which was not done). This situation is called the partial absence of the cause of the obligation. ${ }^{71}$

Therefore, the partial absence of the cause is concluded from the contractual imbalance, in the sense of the interest or utility, resulting from the limiting clause of liability. This is so as Chronopost undertook to fulfill its obligation with the condition (the limiting clause of liability) in the contract limiting or diminishing its obligation. This means that the essential obligation is rendered without a cause, as the limiting clause of liability allows Chronopost to dispose of its obligation and not to bear the burden of compensating the damage suffered by the other contracting party. ${ }^{72}$

Nevertheless, the decision of the French Court of Cassation in the case of Chronopost was criticised by some French legal jurists such as Larroumet, ${ }^{73}$ who confirmed that the decision ruled by the Court of Cassation was inappropriate. This is because the limiting clause of liability may be excluded, to a fair solution by other traditional legal means such as essential error or termination of the contract for nonenforcement. In addition, it is firmly established in the French jurisprudence and the judiciary that the limiting clause of liability may be excluded only if the debtor is guilty of fraud or essential error. However, referring back to the decision of the French Court of Cassation, the error committed by Chronopost does not equal an

71 See Mato Pacin, "Content Control of Standard Terms in Business-toBusiness Contracts in Comparative and European Law," 224-225.

72 Indeed, this view is based on a realistic analysis of the ideas of utility (l'utilité) and equilibrium (l'équilibre) in contractual obligations, and is a repetition of what the French legal jurist Maury said when he defined the cause as the desired equivalent (l'équivalent voulu). See Ashmawi, Causation Theory and Contractual Justice, 101. See also "French Court of Cassation, civil room 1, public sitting of Wednesday 3 July 1996, no of appeal: 94-14800," légifrance, le service public de la diffusion du droit, accessed January 16, 2019,

https://www.legifrance.gouv.fr/affichJuriJudi.do?oldAction=rechExpJuri Judi\&idTexte $=$ JURITEXT000007036953\&fastReqId=934404352\&fastP os $=18$.

73 See Margarita Morales Huertas, "Renovacion del Concepto de Causa en el Derecho Frances, La," Revista de Derecho Privado 16 (2009): 181. Christine Chappuis, "Le Renoncement a la Cause et a la Consideration Dans L'Avant-Projet D'Acte Unifrome OHADA Sur le Droit des Contrats," Uniform Law Review 13, no. Issues 1 and 2 (2008): 267-268. 
essential error. Therefore, the Court of Cassation must respect the limiting clause of liability of Chronopost. ${ }^{74}$

In response to previous criticism, and through precise analysis of the mutual obligations between the parties to the contract, it was supposed that the company, Chronopost, is to guarantee the accuracy and rapidity of its service in exchange for the increase in the price obtained from Banchereau. This is not the basis upon which the nature of the concluded contract refuses that the essential obligation would be limited to the process of delivering the postal parcels only. In addition, there should be a precise date for the implementation of that obligation. ${ }^{75}$ Thus, the Commercial Room of the French Court of Cassation conducted a review of the contract for the purpose of ascertaining the cause of the obligations, to discover that the increase in the price obtained from Banchereau was due to Chronopost's obligation to perform its service in a rapid and accurate manner.

Hence, with this analysis, the Commercial Room of the French Court of Cassation's preference to rely on the causation theory becomes clear. This depends on the basis that, since the limiting clauses of liability could be accepted to be valid when it came to subordinated obligations, the debtor's determination of the extent of its essential obligation or the consequences of its non-enforcement is absolutely not acceptable. ${ }^{76}$ Therefore, the French Court of Cassation ruled to exclude the limiting clause of liability of Chronopost which undermines the essential obligation of the contract so that it becomes just a false idea.

Furthermore, the Commercial Room of the French Court of Cassation confirmed that the failure of Chronopost to perform its service in a rapid and accurate manner on the agreed date specified in the contract (the essential obligation) was not what led to the exclusion of Chronopost's limiting clause of its liability. However, it is mainly

74 See Pascal Frechette, "Qualification des Contrats: Aspects Theoriques, La," Cahiers de Droit 51, no. 1 (Mars 2010): 141-142.

75 "French Court of Cassation, commercial room, public sitting of Tuesday 22 October 1996, no of appeal: 93-18632," légifrance, le service public de la diffusion du droit, accessed January 17, 2019, https://www.legifrance.gouv.fr/affichJuriJudi.do?oldAction=rechExpJuri Judi\&idTexte=JURITEXT000007035966\&fastReqId=232986072\&fastP os $=1$.

76 See Ashmawi, Causation Theory and Contractual Justice, 113. 
because it was opposed with what Banchereau sought to achieve from concluding such a contract, i.e., since the inception of the contract, the limiting clause of liability contravened with an essential obligation of the contract. Besides that, contractual will must not contradict itself, in the sense that the debtor is not intended to be bound and not to be bound at the same time. ${ }^{77}$

\section{The Role of the Causation Theory in Annulling the Arbitrary or Abusive Conditions}

The Commercial Room of the French Court of Cassation in the Chronopost case considered that the limiting clause of liability had to be deemed as not written (clause réputée non écrite) and; therefore, the liability of the debtor (Chronopost) should be considered in light of the general principles of contractual liability. ${ }^{78}$ It should be noted, however, that the consideration of the limiting clause of liability as unwritten is due to the absence of the cause. It follows that there is no longer any question whether the breach by Chronopost of its obligation constitutes an essential error or not, before ruling the full compensation for the damages suffered by the injured party (Banchereau) ${ }^{79}$

77 See Osama Mujahid, The Idea of Essential Obligation of the contract and its Impact on Liability Agreements (Cairo: Dar Alnahdah Alearabiah, 2003), 49.

78 "doit être réputée non écrite la clause limitative de responsabilité insérée dans un contrat de transport fixant l'indemnisation du retard au montant du prix du transport, dès lors que le transporteur, spécialiste du transport rapide garantissant la fiabilité et la célérité de son service, qui s'était engagé à livrer le pli de l'expéditeur dans un délai déterminé, avait, en ne livrant pas dans ce délai, manqué à cette obligation essentielle dont la clause contredit la portée". See "French Court of Cassation, commercial room, public sitting of Tuesday 22 October 1996, no of appeal: 9318632," légifrance, le service public de la diffusion du droit, accessed January 17, 2019,

https://www.legifrance.gouv.fr/affichJuriJudi.do?oldAction=rechExpJuri Judi\&idTexte $=$ JURITEXT000007035966\& fastReqId $=232986072 \&$ fastP os=1. Denis Mazeaud, "Reforme du Droit Francais des Contrats, La," Revue Juridique Themis 44, no. 1 (2010): 248.

79 See Huertas, "Renovacion del Concepto de Causa en el Derecho Frances, La," 181. Benedicte Fauvarque-Cosson; Denis Mazeaud, "L'avant-projet 
However, this decision serves as a starting point for the approach of the French Court of Cassation to exclude the limiting clause of liability in case of a debtor's breach of the essential obligation of the contract without referring to the notion of fraud or essential error. ${ }^{80}$ Through this decision, the Commercial Room of the French Court of Cassation in the Chronopost case considered that the limiting clause of liability could not contravene the essential obligation of the contract. Thus, this raises the question of the validity of the clauses of liability or of the clauses for determining the obligations generally where there is no doubt that the consensual arrangement between the contracting parties cannot be used to determine the existence or scope of the essential obligation of a contract in general. ${ }^{81}$

In other words, the obligation of delivering the postal parcels on the agreed date specified in the contract is an essential obligation; as such, it cannot logically be subject to the consensual arrangement between the contracting parties. ${ }^{82}$ Therefore, the limiting clause of liability is not valid in this case. Accordingly, this decision does not preclude the establishment of limiting clauses of liability or clauses for determining the obligations; rather, it sets certain limits for them. The most important of which is that they do not violate or affect the essence of the contract itself, which is the essential obligation.

The Commercial Room of the French Court of Cassation has used the conventional content of the causation theory to exclude the limiting clause of Chronopost's liability, asserting that there was an obligation in that type of the contract, which cannot be violated, as it represented the interest of the contract. ${ }^{83}$ However, as mentioned

Francais de Reforme du Droit des Obligations et du Droit de la Prescription," Uniform Law Review 11, no. 1 (2006): 114-115.

80 See Mujahid, The Idea of Essential Obligation of the contract and its Impact on Liability Agreements, 65-66.

81 See Attila Dudas, "Survey of the Relevant Literature on the Purpose of Obligations Arising from a Contract in Civil (Causa) and Common Law (Consideration)," Zbornik Radova 43, no. 3 (2009): 414-415.

82 See Chappuis, "Le Renoncement a la Cause et a la Consideration Dans L'Avant-Projet D'Acte Unifrome OHADA Sur le Droit des Contrats," 269.

83 "et qu'en raison du manquement à cette obligation essentielle...". "French Court of Cassation, commercial room, public sitting of Tuesday 22 
earlier, the cause for the contract is objective when its applied to all similar contracts. ${ }^{84}$ Is it, therefore, possible to exclude arbitrary or abusive clauses in contracts of adhesion or model contracts, if they breach an essential obligation in the contract?

The decision in the Chronopost case embedded a new function of the causation theory as an effective means for achieving contractual justice between the contracting parties. ${ }^{85}$ The decision, also, had led to the annulment of the limiting clause of Chronopost's liability, and allowed indirectly to monitor the equivalence of obligations. ${ }^{86}$ In this sense, it is well known that the contract of adhesion (le contrat d'adhésion) has a certain specificity, i.e. either acceptance or rejection of the contract without its parties entering into any negotiations. ${ }^{87}$ This means that the composition of the contract is subject to a uniform pattern. ${ }^{88}$ Thus, if the cause of the obligation is the same in these contracts, regardless of the person who is contracting, then the essential obligation -which is the cause of the corresponding performance- is always the same essential obligation. ${ }^{89}$ This situation applies also to all

October 1996, no of appeal: 93-18632," légifrance, le service public de la diffusion du droit, accessed January 17, 2019,

https://www.legifrance.gouv.fr/affichJuriJudi.do?oldAction=rechExpJuri Judi\&idTexte=JURITEXT000007035966\&fastReqId=232986072\&fastP os $=1$.

84 See footnote no: 10.

85 See Jean-René Binet, “De la fausse cause," RTDciv: Revue Trimestrielle de droit civil 4 (2004): 671.

86 See Stéphanie Porchy-Simon, Droit civil $2 e$ année, les obligations (Paris: Dalloz, 2017), 105.

87 Mustapha Mekki, "The French Reform of Contract Law: The Art of Redoing without Undoing," Journal of Civil Law Studies 10, no. 1 (2017): 230. Neha Ahuja, "Commercial Creations: The Role of End User License Agreements in Controlling the Exploitation of User Generated Content," John Marshall Review of Intellectual Property Law 16, no. 4 (2017): 404.

88 Mo Zhang, "Contractual Choice of Law in Contracts of Adhesion and Party Autonomy," Akron Law Review 41, no. 1 (2008): 138. Aditi Bagchi, "Parallel Contract," University of Pittsburgh Law Review 75, no. 2 (Winter 2013): 168.

89 See Ghozlan, "The Concept of Essential Obligation under the Control of Abusive Clauses: The Study of French and Quebec Legal Systems," 400. Fokou, "La Notion d'Economie du Contrat en Droit Francais et Quebecois," 363. 
model contracts (les contrats types)..$^{90}$ Therefore, if an arbitrary or abusive clause of an adhesion contract or model contract violates the essential obligation, it is deemed as unwritten. ${ }^{91}$

Thus, the causation theory allows for the correction of contractual inequality by rebalancing the content of the contract by nullifying the condition that has been the cause of economic contractual imbalance. ${ }^{92}$ Moreover, the decision of the Commercial Room of the French Court of Cassation establishes a general rule that any arbitrary clause that contravenes the essential obligation of the contract is considered to be unwritten, regardless of the nature or subject matter of the contract. ${ }^{93}$ Subsequently, this theory guarantees the protection and appreciation of Commutative Justice by mending the balance between the contracting parties and protecting the injured one. ${ }^{94}$ This is applicable even if the injured party is professional. The French judiciary is credited with proving that the theory of cause serves as a basis for excluding arbitrary clauses among professionals without having to expand the concept of the term 'consumer' ${ }^{95}$

Moreover, what the Commercial Room of the French Court of Cassation has created as a penalty in the Chronopost case is surprising. Contrary to the traditional ruling that the penalty of the absence of the cause is to annul the entire contract (absolute nullity), the judges of the French Court of Cassation preferred partial invalidity as a penalty in

$90 \quad$ See Ali Bencheneb, "Aspects Caracteristiques Du Droit Algerien Des Contrats D'Affaires," International Business Law Journal 2001, no. 1 (2001): 40.

91 See Ghozlan, "The Concept of Essential Obligation under the Control of Abusive Clauses: The Study of French and Quebec Legal Systems," 400.

92 See Ashmawi, Causation Theory and Contractual Justice, 121.

93 See Eric Gastinel, "French Business Law Update," European Business Law Review 9, no. 1 (1998): 10.

94 See Terré, Simler, Lequette, Droit civil, Les obligations, 320-321.

95 The French judicial rulings of 22 October 1996, No of Appeal: 93-18632, and 3 July 1996, No of Appeal: 94-14800 made it clear that a professional, even if he or she is acting in accordance with the requirements of his or her profession, could be a victim of an arbitrary clause. See Huertas, "Renovacion del Concepto de Causa en el Derecho Frances, La," 181. Jean-Michel Marmayou, "Disappearance of the Cause in the Individual Sponsorship Deal," Romanian Review of Private Law 2011, no. 2 (2011): 266. 
this case to avoid punishing the injured party $;{ }^{96}$ that is, if the court ruled the absolute nullity. Nevertheless, this is the most appropriate and suitable solution since it includes the protection of the injured party (Banchereau), where absolute nullity harms its interests. In addition, it protects the contract itself at the same time, as one of the main priorities of the law is also to maintain contracts the extent possible. ${ }^{97}$

The application of the causation theory under the previous explained French judiciary decision is one of its most important usages since it allowed the judge to rebalance disrupted economic contractual equilibrium. Additionally, as well, it allowed him to maintain the binding force of the contract after its conditions were corrected. This situation has led some legal jurists (the causalistes) to theorise the balance of obligations as an expression of the cause of the obligation itself $^{98}$ and, thus, consider it as a condition for the validity of agreements in general. ${ }^{99}$ Consequently, some legal French jurists openly declared their demand to renew the concept of justice at the core of the contract itself. This is done by developing the idea of proportionality of performances (proportionnalité des prestations) in particular, ${ }^{100}$ i.e. there is a tendency towards abandoning the idea of inviolability of the contractual terms in favor of a new use of the notion of contractual justice. ${ }^{101}$ As a result, in the recent amendment of the French Civil Code (the French Decree N 131-2016 of 10 February

96 See Huertas, "Renovacion del Concepto de Causa en el Derecho Frances, La," 181. Chappuis, "Le Renoncement a la Cause et a la Consideration Dans L'Avant-Projet D'Acte Unifrome OHADA Sur le Droit des Contrats," 268.

97 See the OEPDCC, at 41-42.

98 See Jacques Maury, Le concept et le role de la cause des obligations dans la jurisprudence (Paris: Imprimerie Moderne, 1951), 490.

99 See Ashmawi, Causation Theory and Contractual Justice, 142.

100 See Gilles Pillet, "The Reform of French Contract Law and of the General Rules on Obligations: The Civil Code Faces the Challenges of the Market," International Business Law Journal 2016, no. 3 (2016): 250.

101 See Antoine Guilmain, "Sur les Traces du Principe de Proportionnalite: Une Esquisse Genealogique," McGill Law Journal 61, no. 1 (2015): 118122. Jean Kellerhals; Josette Coenen-Huther; Marianne Modak, "Quelques Problemes, Methodes et Resultats d'une Approche Sociologique des Normes d'Equite," Droit et Societe 4 (1986): 515. 
2016), the French legislature states in Article $1170^{102}$ that: "Any contract term which deprives a debtor's essential obligation of its substance is deemed not written". ${ }^{103}$

Thus, the explanation and analysis of the previous sections show that the causation theory is no longer an abstract philosophical idea, but rather a practice of renewed application. This is due mainly to the French judiciary, which expanded the concept of the causation theory, seeking for contractual justice. ${ }^{104}$ However, it is found that the causation theory in the PDCC is restricted to achieving contractual justice or contractual security that encourages investment in an emerging State. Moreover, contractual security and contractual justice have become the most important aims for legislative systems as a goal

102 "Indeed, Article 1170 is largely in accordance with Article 7.1.6 of the UNIDROIT Principles of International Commercial Contracts of 2016 which states: "a clause which limits or excludes one party's liability for non-performance or which permits one party to render performance substantially different from what the other party reasonably expected may not be invoked if it would be grossly unfair to do so, having regard to the purpose of the contract". Meanwhile, Article 8: 109 of the Principles of European Contract Law clearly prevents invoking the exemption clauses of liability in certain cases". See Yousef Mohammad Shandi; Osama Ismail Mohammad Amayreh, "Depriving the Debtor's Essential Obligation of Its Substance and Its Remedies under the Provisions of Article 1170 of the French Civil Code," Journal of Politics and Law 13, no. 2 (2020): 130.

103 "toute clause qui prive de sa substance l'obligation essentielle du débiteur est réputée non écrite”. Ordonnance $n^{\circ}$ 2016-131 du 10 février 2016 portant réforme du droit des contrats, du régime général et de la preuve des obligations". Smaranda Angheni, "General Considerations on the Contract as the Main Source of Legal Liability between Traders," Law Annals from Titu Maiorescu University 2017 (2017): 13. Liviu Pop, "General Considerations on the Reform of the Right of Obligations in the French Civil Code," Romanian Review of Private Law 2018, no. 1 (2018): 288.

${ }^{104}$ In fact, Article 1170 of the NFCC establishes a theory similar to the theory of Fundamental Breach, used in English law, which states that in case the debtor refrains from performing his essential contractual obligations, then he shall be deprived of invoking the exemption clause or limiting liability clause. See Shandi, "Depriving the Debtor's Essential Obligation of Its Substance and Its Remedies under the Provisions of Article 1170 of the French Civil Code," 130. 
to be pursued within the framework of their national legislation. Here, the Palestinian legislature should amend the legislative articles of the causation theory in the PDCC, similar to what the French legislature did in order to achieve contractual security and contractual justice. Also, it is meant to resolve any judicial dispute in applying the provisions of the causation theory in a way that is incompatible with the specificity of the Palestinian reality, since it lacks legal rules that guarantee justice and contractual security.

\section{CONCLUSION}

The causation theory is one of the legal theories that has witnessed the most significant jurisprudential controversy over the development of legal thought and regardless of the jurisprudence (the anti-causalistes) that called for the need to dispense the idea of cause. However, it has been greatly developed by the French judiciary which essentially expanded the traditional concept of the causation theory. The French judiciary has added a new role for the theory, namely, achieving contractual justice through the annulment of the arbitrary or abusive conditions and the achievement of economic monitoring over the contract. This is in order to ensure the commutative justice between the contracting parties.

However, the Palestinian legislative regulation of the provisions of the causation theory in Articles 135, 136, 137 and 138, and the explanations of the provisions of these articles in the OEPDCC ignore the remarkable modernistic role of this theory in achieving economic contractual equilibrium. Even if the Palestinian judiciary attempted to keep up with what the French judiciary did (the Chronopost's decision and Piller's decision), it would still face many legal obstacles. Perhaps the most prominent of which include: first, the Palestinian legislature's definition of the concept of cause of the obligation in the OEPDCC as the abstract direct purpose that the obligor wants to achieve by obliging himself (objective cause), and the definition of the concept of cause of the contract in the OEPDCC as the personal motive that led the contracting party to conclude the contract. Second, the Palestinian legislature also determined the way that the court may estimate the absence of the cause in an abstract way for the cause of the obligation, and limited the court's role to only verify the legality of the cause of the contract. 
Thus, the Palestinian legislature should amend the legislative articles of the causation theory in the PDCC, similar to what the French legislature did. By doing so, it can achieve contractual security and contractual justice, and resolve any judicial dispute in applying the provisions of the causation theory in a way that is incompatible with the specificity of the Palestinian reality, due to the lack of legal rules that guarantee justice and contractual security. 